\title{
Legal Aspects of the Coastal Zone Management: On-going Process of ICZM in Thailand
}

\author{
Kanongnij Sribuaiam *
}

\begin{abstract}
"Coastal zone" is an area with interface between the land and the sea, and naturally contains unique character with multi-dimensional values, enjoyed by different users, based on different purposes, and finally led to conflicts among various stakeholders. To promote sustainable management of coastal zone as well as sustainable development, a new mechanism called "Integrated Coastal Zone Management or ICZM" was introduced for maintaining both "interdependence" between environment and development and "integration" of various measures, policies, processes, institutions and full public participation through coordinating mechanisms at both the local and national levels. ICZM is used by most coastal countries to ensure that all activities relating to the coast will harmoniously function to achieve common goals rather than replacing the traditional single-sector resources management. Thailand is on the process of introducing ICZM to the existing system.
\end{abstract}

\section{Keywords}

coastal zone, coastal zone management, sustainable management of coastal zone, sustainable development, Integrated Coastal Zone Management ("ICZM")

* Associate Professor \& Deputy Director on Research, Law and Development Research Center at the Faculty of Law of Chulalongkorn University, Thailand. LL.B/LL.M.(Chulalongkorn), LL.M.(Harvard), Docteur en Droit (Nantes). The author may be contacted at: ksribuaiam@yahoo.com/Address: Faculty of Law, Chulalongkorn University, Phayathai Road, Bangkok 10330. Thailand. 


\section{Introduction}

A "coastal zone" is defined as the interface where land and sea meet. It is also known as a heavily exploited area due to its highly valued natural resources. These natural resources not only provide habitats for human settlements, local subsistence and economic development, but also support aquatic and terrestrial living organisms for their food, shelter and habitation. In coastal countries, the population in the coastal zones is increasing, which leads to more conflicts involving the resources used by different users for different purposes. As a result, coastal zones are under constant pressure, resulting in degradation which leads to negative social and economic consequences. To cope with these problems and related aspects such as the conflicts among various stakeholders and policies regulating overexploitation of resources, an effective mechanism is needed in order to maintain and restore the coastal zones, and coordinate different policies in managing the resources. In light of this, a new management system called the Integrated Coastal Zone Management ("ICZM") is being proposed for implementation in the national strategies of many coastal countries.

Coastal areas are significant resources for Thailand in terms of human settlement and economy. For example, major industries such as oil refineries and petrochemical plants are usually located along the coastline, especially on the east coast. Aquaculture, fisheries and tourism are also major economic activities in the coastal zones, contributing large amounts of income at both the local and national scales. Therefore, Thailand' s economic activities are centered around these areas and thus, intensively put these areas under pressure. To withstand such pressure and fill gaps in the existing coastal management, ICZM is being introduced to Thailand as a new mechanism to protect the environment and to promote sustainable development of the coastal zone. This new mechanism includes cross-sectoral management, strategic environmental assessment and local community participation. To initiate ICZM in the Thai system, it is necessary to explore the relevant concepts of the coastal zone. After this comparative analysis, ICZM, as a new concept of management, needs to be well identified and finally, the method of applying such a management system must be developed.

\section{Revisiting Concepts Relevant to the Coast}

As a ramification of a shift from the old paradigm of "Freedom of the Sea" to the new 
paradigm of "The Law of the Sea," the area of the high seas was vastly reduced, while the area of the territorial sea was significantly extended.

\section{A. "Freedom of the Sea": An Old Paradigm of the World's Ocean Governance}

In 1493, the world was divided by Pope Alexander VI into two - the west and the east of which Spain occupied the area west and Portugal the area east of the Azores. With the effort of Spain in claiming exclusive navigation rights of the western Atlantic Ocean and that of Portugal in claiming the same rights for the southern Atlantic Ocean and Indian Ocean, the world' s oceans during the fifteenth century were also divided. ${ }^{1}$ As a result, the doctrine of "Freedom of the Seas" was developed in the seventeenth century as a reaction of the Dutch who had a strong interest in trading with the East Indies through the Dutch East India Company. This concept originated from the famous treatise Mare Liberum ${ }^{2}$ which was written in 1609 by Hugo Grotius, a Dutch jurist. He referred to the fluid and mobile nature of the sea to explain the impossibility and impracticality of considering the ocean as "property" that can be divided, owned, or occupied. He applied "natural law" theory and endorsed the necessity of leaving the oceans open for the purposes of intercommunication and free trade among the world' $s$ nations separated by water. ${ }^{3}$ For about 400 years, until the middle of the twentieth century, "Freedom of the Seas" was the dominant paradigm for governance of the world' s oceans. 4

Although the concept of "Freedom of the Seas" was supported by coastal nations, the nations still needed to control the band of sea which was immediately adjacent to the shorelines as a protective zone against armed ships for security reasons. Control of the coastlines was developed by custom during the late eighteenth century as the concept of the territorial sea. 5 Within this zone, the coastal nations could control fishing,

1 See The Freedom of the Sea or The Right which Belongs to the Dutch to Take Part in the East Indian Trade by Hugo Grotius, available at http://upload.wikimedia.org/wikipedia/commons/7/7b/Grotius_Hugo_The_Freedom _of_the_Sea_(v1.0).pdf (last visited on Oct. 20, 2009). On the law and dominion of the sea at that time, see also William G. Grewe, The Epochs of International Law 129-133 (2000)

On the maritime law of Hugo Grotius, see V. Lowe, The LaW of the SeA 3-5(1999).

B. Cicin-Sain \& R. Knecht, Integrated Coastal Management 68 (1998).

5 In the $17^{\text {th }}$ and $18^{\text {th }}$ centuries, the breadth of territorial sea was not clearly identified. Thus, Cornelius van Bynkershoek, the Dutch jurist made the Cannon Shot Rule, making the State's sovereignty over the sea to extend seawards as far as it could fire a cannonball from its shore. At that time, the distance that cannonballs could be projected was approximately 3 nautical miles. This rule was commonly accepted by a large number of States at the time as customary international law. See Jack L. Goldsmith \& Eric A. Posner, The Limits of International LaW 59 (2005). 
set customs, exert police power and allow "innocent passage" of foreign vessels passing through the zone. Coastal nations possessed territorial seas which were relatively narrow. National activities beyond such territorial waters were limited primarily to navigation, coastal fishing, and in a few cases, distant-water fishing and cable lines. 6

\section{B. Paradigm Shift: from the "Freedom of the Sea" to the "Law of the Sea"}

Unlike the stable period of "Freedom of the Seas" which represented the old paradigm of the world's ocean governance from the 1600s until the end of World War II, the second period of the law of the sea which represented the new paradigm since 1945 has seen a constant growth of international and national activities relating to ocean law and policy. In response to the discoveries of oil and gas in the Gulf of Mexico, new development was initiated by the United States to assert jurisdiction over the resources of the continental shelf up to 200 nautical miles from shore. This put pressure on the development of international norms in using different zones of the seas and the ocean. Starting in 1958, three conferences on the law of the sea were held by the United Nations focusing on the rights and duties of nations regarding the ocean.7

The first United Nations Conference on the Law of the Sea ("UNCLOS I") was held in Geneva in 1958 and the second United Nations Conference on the Law of the Sea ("UNCLOS II") was held in 1960. UNCLOS I introduced four conventions at the global level: (1) the Convention on the Territorial Sea; (2) the Convention on the High Seas which recognized the freedom of fishing; (3) the Convention on the Continental Shelf which recognized the coastal State' s sovereign right to explore and exploit its natural resources, including living organisms belonging to sedentary species; and 4) the Convention on Fishing and Conservation of the Living Resources of the High Seas which recognized the right of fishing in the high seas. 8 With the lack of "legal solidarity" among them, however, the four conventions were not linked and were regarded as an ad hoc approach.9

Although these four conventions were widely accepted as codifying international law, major issues such as the allowable breadth of territorial sea and continental shelf claims and responses to increase of stresses on fishery stocks and the marine environment were not adequately addressed.10 Attempts of both UNCLOS I and

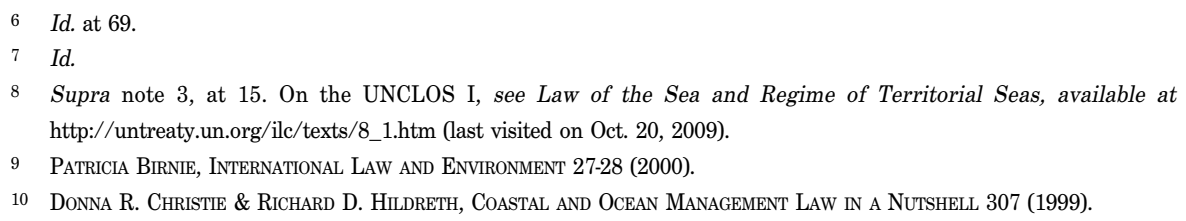


UNCLOS II to establish a special coastal fishery control limit of up to 12 nautical miles failed. As a result, most coastal States claim an Exclusive Economic Zone of up to 200 nautical miles from their baselines in order to control foreign fishing. ${ }^{11}$

The third United Nations Conference on the Law of the Sea ("UNCLOS III") was convened in 1973. After the long process of negotiation, drafting, consensus building and decision making in 1982,12 UNCLOS III finally adopted the United Nations Convention on the Law of the Sea ("LOS Convention") as a single package treaty in which individual principles of the treaty cannot be accepted or rejected separately. In late 1993, the treaty had the requisite 60 ratifications to enter into force in November 1994.13

\section{Dividing Coastal-Marine Zones under the New Paradigm}

The LOS Convention is regarded as a new "constitution" for the world' s oceans. With 320 articles, the LOS Convention addresses all issues regarding the ocean, and establishes international norms for ocean governance by, for example, legitimizing the concept of 200 nautical-mile Exclusive Economic Zones ("EEZ") under national jurisdiction, protecting most navigational freedoms, and establishing 12 nautical miles as the maximum width of territorial seas. ${ }^{14}$ As the constitution of the world' s oceans, LOS Convention contains not only the "rights of nations" relative to the ocean and resources which are carefully spelled out but also maintains the "duties and obligations of nations" in the exploitation of the oceans and resources. In summary, LOS Convention contains the following innovative components: (1) EEZ; (2) the concept of "sovereignty" in the context of EEZ; (3) the archipelagic state and the concept of archipelagic waters; (4) formal recognition of the common heritage of mankind; (5) establishment of the International Seabed Authority; (6) comprehensive international environmental protections; (7) a new regime for marine scientific research; (8) an advanced framework for technological cooperation and development; (9) a comprehensive system of peaceful settlement of disputes; and (10) reservation of the deep seafloor for peaceful purposes. 15

By extending the limit of the territorial sea to 12 nautical miles (Article 3), and introducing the concept of EEZ (Articles 55-75), the area of the high seas in which

\footnotetext{
11 Supra note 9 , at 28.

12 For details on the painstaking process of UNCLOS III, see United Nations Convention on the LaW of the SEa 1982: A CommentaRy I 29-134 (Myron H. Nordquist ed., 1985)

13 Supra note 10, at 309-311.

14 Supra note 4, at 69.

15 Id. at 70-71.
} 
freedom of fishing can still apply was vastly reduced.16 With the conclusion of the LOS Convention, the oceans can be divided in five major zones: a) territorial sea; $b$ ) contiguous zone; c) EEZ; d) continental shelf; and e) high seas.

However, in terms of ecological systems and human utilization of various resources within the system, the coastal-marine spectrum can be identified as the following five zones:17 a) inland areas - areas which affect the oceans mainly via rivers and nonpoint sources of pollution; b) coastal lands - wetlands, marches, and the like where human activity is concentrated and directly affects adjacent waters; c) coastal waters - estuaries, lagoons and shallow waters, where the effects of land-based activities are dominant; $d$ ) offshore waters - areas out to the edge of national jurisdiction of 200 nautical-miles offshore; and e) high seas - areas beyond the limit of national jurisdiction.

\section{Capturing Nature of Coastal Zone}

The word "coastal zone" has special characteristics since it has a unique dynamic significance for social and economic systems as well as environmental systems. From both administrative and scientific viewpoints, it is accepted that what constitutes the coastal zone depends on the particular purpose. The extent of the coastal zone varies depending on the nature of the problem. Therefore, boundaries of the coastal zone can be extended as far as necessary in order to achieve the objectives of coastal management.

\section{A. Defining Coastal Zone}

To define the term "coastal zone," it can only be said in a very general sense that the coastal zone is the interface between the land and the sea, or it is the area where the land and the sea meet. Thus, the coastal zone conveys the notion of a land-sea interface having two axes: one axis is parallel to the shore or "long shore," and the other axis is perpendicular to the shore or "on/off shore." There is less controversy concerning delineation of the long shore axis since it does not widely cross different boundaries of different environmental systems. In contrast, there is considerable debate on the delineation of the on/off shore axis. ${ }^{18}$ Discussions on the delineation of the coastal zone are polarized between the preference to use an ecosystem-based boundary and the preference to use a legal-administrative-economic based boundary which is consistent

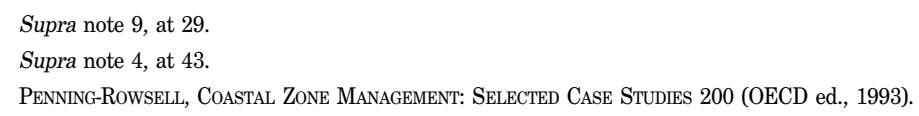


with governance jurisdictions but may or may not always relate to ecosystem boundaries. ${ }^{19}$ What is more important is that the term "coastal zone" should be identified or defined in a way to promote the sustainable utilization and environmental protection of the ecosystem for the sake of both the present and future generation. 20

\section{B. Unique Character of Coastal Zone}

The natural character of the coastal zone is unique because it contains multidimensional values: ecology, economic, recreation and habitat. For ecological value, it provides rich and diverse ecosystems and resources. For example, the combination of freshwater and salt water in coastal estuaries creates some of the most productive and richest habitats on earth. In terms of economic value, it is the site for port and harbor facilities and is the location for some types of industrial processes requiring water cooling, such as power generation plants. These activities help generate large monetary benefits for coastal nations. From a recreational aspect, it is used as the site for resorts and as vacation destinations contributing to high earnings in the tourism industry for coastal nations. ${ }^{21}$ For habitat value, it is serving as home to more than half of the world' s population. Two-thirds of the world's largest cities are situated on the coast and the populations of coastal areas are growing faster than inland population. In 1994, World Bank experts estimated that two-thirds of the population of developing nations would be living along the coast by the end of the twentieth century. Combination of these values amount to the finding that the coasts are an incalculable asset and an important part of the national patrimony for most coastal nations. ${ }^{22}$

Responding to the multi-dimensional values of coastal zone, it is unavoidable to have multipleusers engaged in multiple activities, which thus also requires multiple controllers to exercise their inter-ministerial mission on the protection and development of the coastal spaces. By its nature, any coastal issue requires multi-disciplinary reflection, as well as, sectoral policy integration from all levels: national, regional and local. Usually, the coast is not well understood as a place of a distinct territorial unity. Rather, it is always perceived as a place of conflict both in utilization and in sectoral interactions of policies. As a result, there is an increasing awareness of the need for policy integration if sustainable economic and environmental benefits are to accrue to present and future generations. 23

19 Id. at $15-16$

$20 \quad$ Id. at 16.

21 Supra note 4 , at 15.

22 Milen Dyoulgerov, ICM Basics, What is the coast? Ref. of 24 Frbruary 2005, available at http://www.globaloceans. org/story/icm_coast.html (last visited on Oct. 10, 2009).

23 Supra note 18 , at 15 . 


\section{Managing the Management of Coastal Zone}

The concurrence of all activities on the coastal zone resembles the concept of interdependency among natural dynamics, socio-economic processes and the evolution of value systems. Such concurrence can be divided into two features: the types of users, and those of diversity in regulation styles. That is expressed as a multi-dimensional feature of the coastal space. The question is how to apply all policies to the coast rather than that of how to define the coast. In addition, the policy setting and regulation tools are needed considerably to integrate all dynamics. In this context, the coast appears as a forum of competition among regulations where institutional framework must be designed for all actors to obtain social recognition and to prove their efficiencies.

The management of coastal zone either by focusing on the coastal zone or by considering also the coastal-marine spectrum entails challenges to be confronted on issues such as the nature of property, the nature of government interests, and the nature of government institutions. In terms of the nature of property in coastal areas, there tends to be a continuum of ownership: private property tends to predominate in inland areas; a mix of public and private property tends to exist on coastal lands; and public property is dominant in coastal waters and offshore waters. This generalization varies from country to country according to cultural conceptions of private and public property. For example, coastal lands and coastal waters in many South Pacific islands are often communally controlled by village-level councils of elders.

In terms of the nature of government interests, local or provincial interest tend to predominate in inland areas, while there tends to be a mix of local, provincial, and national interests on coastal lands and in coastal waters. Moving farther out, ultimately to offshore waters and the high seas, national and international interests become most important. In terms of the nature of government institutions, there are differences in various zones. On the land zone, there are government institutions with "multiplepurpose" at the local and provincial levels to address such questions as control of land use and conflicts arising among its usage. On the water zone, there tends to be only "single-purpose" agencies at provincial or national level to operate each sector concerned primarily with a single use of the ocean, for example, fisheries operations or oil and gas extraction. 24 


\section{General Principles in Managing the Coastal Zone}

At the international level, there are two sets of legal norms providing general principles in managing the coastal zone: a set of the Conventions on the Law of the Sea in the form of hard law; and a set of declarations on the environment in the form of soft law, both of which are used to supplement each other.

\section{A. Connection between the Law of the Sea and the 1972 Stockholm Declaration on the Protection of Marine Environment}

Since UNCLOS I did not provide special provisions on the protection of the marine environment, it can be practically interpreted that States can enjoy the principle of high seas freedoms through any activities including ocean pollution with the limitation that they must act with reasonable regard for the rights of others. However, other legal instruments that followed had some clauses on marine protection. An example is found in Articles 24 and 25 of the 1958 High Seas Convention which require States to prevent oil pollution from ships, pipelines and seabed operations, and pollution from radioactive substances. Marine pollution was also an important issue at the 1972 Stockholm Conference on the Human Environment. Principle 21 of the Stockholm Declaration provides that: "States have, in accordance with the Charter of the United Nations and the principles of international law, the sovereign right to exploit their own resources pursuant to their own environmental policies, and the responsibility to ensure that activities within their jurisdiction or control do not cause damage to the environment of other States or of areas beyond the limits of national jurisdiction." 25 Recommendations of the Stockholm Conference also influenced the adoption of the 1972 London and Oslo Dumping Conventions, and the 1973 Convention for the Prevention of Pollution from Ships ("MARPOL").

Unlike UNCLOS I, the LOS Convention of 1982 strongly expressed the obligation to protect the marine environment in Articles 192-195. Article 192 of LOS Convention explicitly stated in Section 1 under the General Provision that "States have the obligation to protect and preserve the marine environment," while Article 193 of the same document declared that "States have the sovereign right to exploit their natural resources pursuant to their environmental policies and in accordance with their duty to protect and preserve the marine environment." Although some parts of the LOS 
Convention drew on the language of Principle 21 of the Stockholm Declaration, 26 it is found that the former is more strongly articulated than the latter. This can be seen in Article 194 and other following articles where the protection of the marine environment does not apply only to States and their marine environment but also covers the marine environment as a whole including the high seas. Another example is the meaning of environment which includes "rare and fragile ecosystems as well as habitat of the depleted, threatened or endangered species and other forms of marine life." This definition extends the scope of State obligation not limited only to the protection of economic interests, private property, but also the human use of the sea. 27

\section{B. Connection between the Law of the Sea and Agenda 21 of the 1992 Rio Conference Report on Environment and Development}

The great impact of the LOS Convention can be identified as a milestone in creating a new model for international environmental law, and, at the same time, in fundamentally changing some concepts of the international law of the sea on three issues: changes from freedom of the sea to comprehensive legal obligation for pollution control; balance between freedom of navigation and fishing as powers of flag States and effective regulation and control of coastal States; and emphasis on responsibility and liability for environmental damage is replaced by international regulation and cooperation in protecting the marine environment. The new concepts of the LOS Convention were used in Agenda 21 of the 1992 Rio Conference Report on Environment and Development as the "international basis upon which to pursue the protection and sustainable development of the marine and coastal environment and its resources", even though Agenda 21 also developed its own innovative factors that are not presented in LOS Convention. Agenda 21 initiated the precautionary and integrated approaches to protect the marine and coastal environment by shifting focus from the source of marine pollution to the prevention of environmental degradation and the protection of ecosystems. Another innovation of Agenda 21 is linking the protection of EEZ with sustainable development of coastal areas and with sustainable use of marine living resources. 28

\footnotetext{
Philippe Sands, Principles of International EnVIRonmental LaW 397 (2003).

Supra note 9, at 352.

Supra note 9, at 349.
} 


\section{Two Central Concepts of the 1992 Rio Conference on Environment and Development: Interdependence and Integration}

For the concept of interdependence, compartments in the old paradigm, which regarded the planet as a large world in which human activities and their effects were compartmentalized within nations, within sectors (energy, agriculture, trade), and within broad areas of concern (environment, economics, social) have to be dissolved and be replaced by the new paradigm of interdependence. Under the new paradigm, the world has been facing a series of environmental crises which are linked to patterns of economic development prevalent in the North and the South and in the economic relationships between the North and the South. These patterns underscore the inescapable fact of interdependence, in other words, the interdependence between environment and development. The various global crises that have seized public concerns are not separate crises as an environmental crisis, a development crisis, or an energy crisis, but they are all one crisis. The concept of interdependence leads to the need to have a concept of integration, in particular the integration of environment and development policy. ${ }^{29}$

For the concept of integration, the new paradigm requires not only integration of environment and development policy, but also integration among sectors, and integration among nations, especially between the North and the South. Such integration of environment and development can be called "sustainable development." 30 The general goal of sustainable development is to meet the need of the present without compromising the ability of future generations to meet their own needs. Sustainable development is a new paradigm of integration of environment and development in which the equilibrium between development and environmental protection must constantly be readjusted, as well as a new paradigm of integration of different management approaches. Sustainable development maintains three main things: 1) economic development with human beings as the central concern; 2) environmental development with environmentally sensitive use of natural resources, ecological processes, life support systems, and biological diversity; and 3) equitable development with equity in the distribution of benefits from development. It contains

29 Supra note 4 , at $81,82$.

30 The 1992 Rio Declaration reaffirms the concept of "sustainable development" which was formerly adopted at the 1972 Stockholm Conference. The 1992 Rio Conference provides 27 principles to promote such concept around the world. The term "sustainable development" was initially used by the Brundtland Commission in the Report of the World Commission on Environment and Development. See U.N. Doc.A/RES/42/187 (Dec. 11, 1987). For details, see V. Lowe, Sustainable Development and Unsustainable Arguments, in International LAW AND Sustainable DeVElopment 25-26 (A. Boyle \& D. Freestone eds., 1999). 
both inter-generational equity by not foreclosing the options of future generations, and intra-generational equity by fulfilling obligations to other nations and the international community. 31 One necessary element of sustainable development is an integrated decision-making or policy process. 32

\section{Specific Principles for the Ocean and Coastal Management under Chapter 17 of Agenda 21}

Chapter 17 is the longest chapter of Agenda 21 with a length of 42 pages and is one of the most complex chapters. Its major prescriptions are on ocean and coastal management under the title of "Protection of the Oceans, All Kinds of Seas, Including Enclosed and Semi-Enclosed Seas, and Coastal Areas and the Protection, Rational Use and Development of Their Living Resources." The introduction of Chapter 17 stresses both the importance of oceans and coasts in the global life support system and the positive opportunity for sustainable development that ocean and coastal areas represent. The introduction stresses a key point underlying the whole chapter by providing that new approaches to marine and coastal area management with integrated, precautionary and anticipatory content will be needed. 33

\section{Integrated Management and Sustainable Development of Coastal Areas and EEZ}

Chapter 17 calls for coastal nations to commit themselves to integrated management and sustainable development of coastal areas and the marine environment under their national jurisdiction. Integration is emphasized with the application of preventive measures, precautionary approaches and full public participation. Integrated policy and decision-making processes and institutions are required for integrated management and

31 In spite of the definition of "sustainable development" given by the Brundtland Commission, the term contains both strength and weakness in the sense that it means different things to different people. Biliana CICIN-SAIN and Robert W. KNECHT provide three main elements of "sustainable development" as 1) Economic Development 2) Environmental Development, and 3) Equitable development. For more details on multiple dimensions of sustainable development, see Baleshwar Thakur (ed.), Perspectives in Resource Management in Developing Countries I (2003).

32 Supra note 4 , at $84-85$.

33 Chapter 17 covers seven major program areas: 1) Integrated management and sustainable development of coastal areas and EEZ; 2) Marine environmental protection; 3) Sustainable use and conservation of living marine resources of the high seas; 4) Sustainable use and conservation of living marine resources under national jurisdiction; 5) Addressing of critical uncertainties in management of the marine environment and climate change; 6) Strengthening of international and regional cooperation and coordination; and 7) Sustainable development of small islands. Among them, only the areas on 1), 2), and 4) will be particularly focused as they are more relevant to issues on the coastal areas. Supra note 4, at 86-87. 
sustainable development of coastal and marine areas through "coordinating mechanisms" at both the local and national levels.

Chapter 17 suggests a series of actions to be conducted by the coordinating institutions such as preparation of coastal and marine use plans; environmental impact assessment and monitoring; contingency planning for both human-induced and natural disasters; improvement of coastal human settlements; conservation and restoration of critical habitats, and integration of sectoral programs. Chapter 17 calls for "cooperation among states" in the preparation of national guidelines for "integrated coastal management" and the undertaking of measures to maintain biodiversity and productivity of marine species and habitats under national jurisdiction. Similarly, it emphasizes the need for "international cooperation" on both a bilateral and multilateral basis to support national efforts by coastal States in the objectives and activities specified in Chapter 17.

Chapter 17 also requires information collection on coastal and marine physical systems and uses; information collection on both natural science and social science variables; education and training in integrated coastal and marine management; capacity building including human resource capacity; support of pilot demonstration programs and projects in integrated coastal and marine management; and establishment of centers of excellence in the area. Finally, Chapter 17 strongly affirms the need to include traditional ecological knowledge and socio-cultural values as an input to management and the importance of coastal areas for indigenous peoples. 34

\section{Marine Environmental Protection}

Chapter 17 calls for coastal nations to increase their efforts to deal with both land-based and sea-based sources of marine pollution. Although land-based sources account for as much as $70 \%$ of the pollution, there is no global scheme to address this issue. Therefore, Chapter 17 stresses the need for a precautionary and anticipatory approach to prevent degradation of the marine environment. It requires nations to commit themselves to prevent, reduce and control degradation of the marine environment so as to maintain and improve its life-support and productive capacities. It also requires the control of land-based sources to integrate coastal and ocean management. Finally, Chapter 17 calls for additional measures to reduce degradation of the marine environment from seabased activities, including control of pollution from shipping, dumping, offshore oil platforms and ports. 35 


\section{Sustainable Use and Conservation of Living Marine Resources under National Jurisdiction}

Chapter 17 refers to fisheries management in EEZ and other areas under national jurisdiction by reaffirming basic frameworks in the Law of the Sea Convention. It also addresses other problems such as local overfishing, unauthorized incursions by foreign fleets, ecosystem degradation, overcapitalization and excessive fleet sizes, undervaluation of catch, etc. 36

\section{Managing the Coastal Zone by Applying the Concept of the Integrated Coastal Management}

A coastal zone is composed of complex systems where economic development and social needs conflict with the protection of the environment. Evolution of the concept of coastal zone management and the implication for environmental management and policy have recently introduce ICZM as a set of approaches and tools for the sustainable development of coastal zones.

\section{A. Definition of Integrated Coastal Zone Management}

Although Chapter 17 of Agenda 21 describes the need for integrated coastal management, there was little discussion of the meaning of ICZM, its main elements and methods. Thus, there are a number of efforts by international entities to further define, interpret and implement the ICZM concept. Integrated coastal zone management is a dynamic and multidisciplinary process of "managing the management" that combines "coastal area management" with "coastal resource management." Its objective is to promote sustainable development as well as sustainable management of coastal zones by overcoming the problem of the fragmentation of sectoral management and policies and the condition of separation of jurisdictions among different levels of government at the land-water interface and the inconsistency of different decisions makers in making coastal management policies at the macro level. ICZM applies the principles of interdependence and integration from the United Nations Conference on Environment and Development ("UNCED"). It also integrates all components of ICZM just with the same manner that factors of the coastal ecosystems used to be interconnected.

The goal of ICZM is to balance environmental, economic, social, cultural and 
recreational objectives within the limits set by natural dynamics. Such various objectives lead to the integration of various instruments as well as the integration of all relevant policy areas, sectors and levels of administration including the integration of all relevant sectors: all levels of government, the private sector, local communities, coastal and marine stakeholders and non-governmental organizations who play significant roles in determining the use of coastal lands and waters. ICZM is used to ensure that all activities will harmoniously function to achieve agreed common goals rather than replacing the traditional single-sector resource management.

In other words, ICZM is not a "one size fit all" concept which means that it is not a fixed approach that can be applied in a wholesale fashion to all situations and it is not a methodology based on any single nation' s approach to coastal zone management. A key part of ICZM is the design of institutional processes to accomplish this harmonization in a politically acceptable manner. The well established ICZM process covers information collection, planning, decision making, management and monitoring of implementation. It uses the participation and cooperation of all stakeholders to assess the societal goals in a given coastal area and to take actions to collectively meet such goals.

ICZM is thus an alternative management process that is introduced and employed in some coastal countries by initiating into their planning process, setting up key factors in a management program and by enabling legislation to define the term and to specify its geographic area. Since the ICZM concept pertains to a defined geographic area, the institutional framework of the particular area is a significant factor and requires adjustment to suit ICZM.

\section{B. Five Dimensions of Integration Served by ICZM}

There are five dimensions of integration that ICZM employs in managing the coastal zone, namely, inter-sectoral integration, inter-governmental integration, spatial integration, science-and-social science management integration and international integration which can be elaborated as follows: ${ }^{37}$

- Inter-sectoral Integration is the integration among different sectors involving the coastal zone. It usually leads to conflicts among governmental agencies in different sectors. This covers both the horizontal integration among different coastal sectors, such as fisheries, aquacultures, coastal tourism, etc., and the vertical integration between coastal and marine sectors, such as oil and gas development, marine mammal protection, mining, etc. 38

$37 \quad$ Id. at 45.

38 Id. 
- Inter-governmental Integration is the integration among different levels of government namely national, provincial and local governments, since they tend to play different roles, address different public needs, and have different perspectives, according to their missions, authorities and duties. These differences often pose problems in achieving harmonized policy development and implementation between national and sub-national levels. 39

- Spatial Integration is the integration between the land and ocean sides of the coastal zone. Practically speaking, there is always a strong connection between land-based activities and the ocean-based activities involving water quality, fish productivity, etc. In addition, different systems of property ownership and government administration that predominate on the land and ocean sides of the coastal zone usually complicate the different goals and policies. 40

- Science-and-social science Management Integration is the integration among different disciplines, both in science and social science that are required for coastal zone management. While scientists focus on natural sciences relating to the oceans and coasts, social scientists focus on such issues as coastal human settlements, user groups and management processes that govern the oceans and coastal activities. For example, among other disciplines, systematic geography is a discipline concerned with the processes that differentiate places in time and space. Within systematic geography, there are two sub-disciplines: physical geography, which examines the natural processes occurring at the Earth's surface that provide the physical setting for human activities, embracing climatology, geomorphology, coastal and marine geography, geography of soils, biogeography, etc., and human geography which deals with social, economic, and behavioral processes that differentiate places, covering cultural geography, political geography, agriculture and land use, regional development and planning, etc. 41

- International Integration is the integration among nations which is needed when multiple nations border enclosed or semi-enclosed seas or there are international disputes over fishing activities, transboundary pollution, establishment of maritime boundaries, passage of ships, and other issues. Although in many instances, coastal and ocean management questions are within the purview of national and sub-national governments within national jurisdiction zones (200 nautical mile EEZs, extended fishery zones), in many other cases, nations face ocean and coastal management problems vis-a-vis their neighbors and thus must seek internationally negotiated solutions. Typically, the national government plays the leading role in such negotiations. 42 


\section{On-going Process of ICZM in Thailand}

With its coastline of around 2,700 kilometers covered by sandy beaches, mangrove forests, cliffs, rocky beaches, and salt marshes, Thailand possesses two maritime facades separated by the isthmus of Kra: one on the Gulf of Thailand. which is an integral part of the Asian continent and South China Sea with about 1,900 kilometers of coastline, and the other one on the Andaman Sea of the Bay of Bengal with approximately 800 kilometers of coast extending northward from the Malaysian border to the Burmese border. ${ }^{43}$ Thailand is in the process of introducing ICZM as a new mechanism to improve the existing system of managing the coastal zone.

\section{A. Concepts on Integrated Management and Sustainable Development of Coastal Areas Should be Set as Country's Goals}

According to Chapter 17 of Agenda 21, if Thailand aims to introduce ICZM into its jurisdiction, the concept of integrated management and sustainable development of coastal areas should be set as one of Thailand's goals. Such goal should provide objectives, activities and means of implementing the integrated management and sustainable development of coastal areas.

Map 1 : Thailand and Its Neighbors

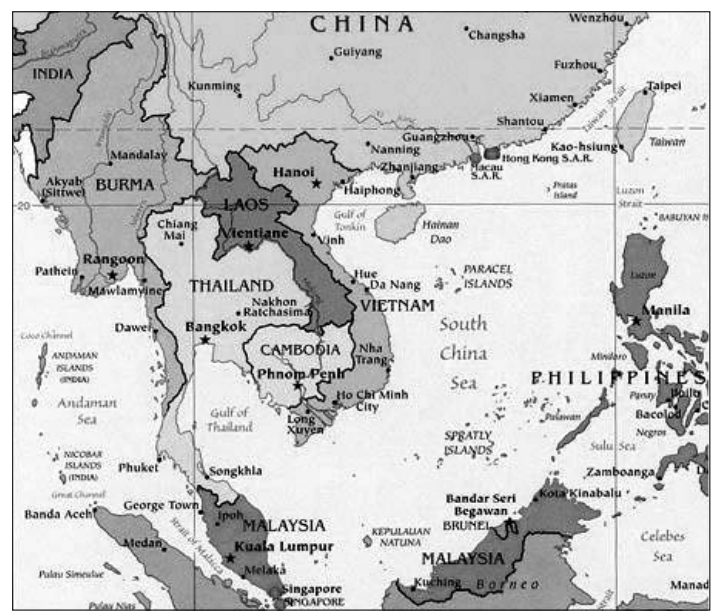

43 R. Tokrisna, P. Boonchuwong \& P. Janekarnkij, A Review on Fisheries and Coastal Community-based Management Regime in Thailand, A paper submitted to International Center for Living Aquatic Resources Management (July 


\section{Objectives of the Integrated Management and Sustainable Development of Coastal areas under Chapter 17 of Agenda 21}

In setting the concept of integrated management and sustainable development of coastal areas as Thailand's goals, it needs to identify the objectives of such concepts clearly enough to be implemented, particularly through ICZM, which can be demonstrated in details as follows:44

- Interactions of various types of the uses of coastal zone - by identifying the existing projects on the coastal areas and focusing on well-defined issues concerning coastal management.

- Compatibility and balance of uses - by means of promoting integrated policy, decision-making process and involved sectors.

- Application of preventive principle and precautionary principle - by introducing the two principles to the planning and implementation of project as well as the prior assessment and the systematic observation on impacts of major projects.

- Changes in people's values in the usage of coastal areas - by developing and promoting the application of innovative methods such as national resource, environmental accounting, etc.

- Participation of individuals, groups and organizations - by providing them access to information, opportunities for consultation and participation in planning and decision-making at appropriate levels.

\section{Activities to Achieve the Objectives in the Integrated Management and Sustainable Development of Coastal Areas under Chapter 17 of Agenda 21 \\ To achieve the concept of integrated management and sustainable development of coastal areas, Thailand has to initiate certain types of activities, namely, management- related activities, activities on collecting data and information regarding the usage of coastal recourses and activities on cooperation and coordination at regional and international levels.}

1997 ) at 38, available at http://www.worldfishcenter.org/Pubs/Way\%20Forward/15\%20tokrisna.pdf, a. 8-9. (last visited on Oct. 10, 2009).

44 See Report of the United Nations Conference on Environment and Development (Rio de Janeiro, 3-14 June 1992) or AGENDA 21, Chap. 17, available at http://www.un.org/Depts/los/consultative_process/documents/A21-Ch17.htm (last visited on Oct. 10, 2009). 
- Management-related Activities: Thailand should consider establishing or strengthening appropriate national coordinating mechanisms for the integrated management and sustainable development of coastal and marine areas and their resources. Such mechanisms should be set up in the form of a high-level policy planning body with offices at both local and national levels. In operating the functions, the national coordinating mechanisms must consult with academic and private sectors, non-governmental organizations, local communities, resource user groups, and indigenous people, as appropriate. 45 In addition, Thailand should undertake measures to maintain biological diversity and productivity of marine species and habitats under national jurisdiction. This can be done with the support of international organizations. The measures might include other related activities such as surveys of marine biodiversity, inventories of endangered species and critical coastal and marine habitats, establishment and management of protected areas, and support of scientific research and dissemination of its results. 46

\section{- Activities on Data and Information of the Uses of Coastal Recourses Thailand} should improve its capacity to collect, analyze, assess and use information for sustainable use of resources including environmental impacts of activities affecting the coastal and marine areas. The use and assessment of information for management purposes should be supported especially in view of the intensity and magnitude of the changes occurring in the coastal and marine areas. Activities related to data and information also include: 1) development and maintenance of databases for assessment and management of coastal areas and all seas and their resources; 2) development of socio-economic and environmental indicators; 3) regular environmental assessment of the state of the environment of coastal and marine areas; 4) preparation and maintenance of profiles of coastal area resources, activities, uses, habitats and protected areas based on the criteria of

45 Scope of the functions should cover the following areas: 1) Preparation and implementation of land and water use and siting policies; 2) Implementation of integrated coastal and marine management and sustainable development plans and programs at appropriate levels; 3) Preparation of coastal profiles identifying critical areas, including eroded zones, physical processes, development patterns, user conflicts and specific priorities for management; 4) Prior environmental impact assessment, systematic observation and follow-up of major projects, including the systematic incorporation of results in decision-making; 5) Contingency plans for human induced and natural disasters, including likely effects of potential climate change and sea level rise, as well as contingency plans for degradation and pollution of anthropogenic origin, including spills of oil and other materials; 6) Improvement of coastal human settlements, especially in housing, drinking water and treatment and disposal of sewage, solid wastes and industrial effluents; 7) Periodic assessment of the impacts of external factors and phenomena to ensure that the objectives of integrated management and sustainable development of coastal areas and the marine environment are met; 8) Conservation and restoration of altered critical habitats; 9) Integration of sectoral programs on sustainable development for settlements, agriculture, tourism, fishing, ports and industries affecting the coastal area; 10) Infrastructure adaptation and alternative employment; 11) Human resource development and training; 12) Public education, awareness and information programs; 13) Promoting environmentally sound technology and sustainable practices; and 14) Development and simultaneous implementation of environmental quality criteria.

46 Supra note 44. 
sustainable development; and 5) exchange of information and data. To fulfill the above-mentioned tasks, Thailand should strengthen and improve its capacity in data and information activities by establishing cooperation with other countries through sub-regional and regional mechanisms. ${ }^{47}$

- Activities on Cooperation and Coordination at Regional and International Levels: As part of its efforts to promote integrated management and sustainable development of coastal and marine areas, Thailand should prepare national guidelines for integrated coastal zone management and development drawing on existing experience. This should be supported and supplemented by international cooperation and coordination on a bilateral basis or within interregional, regional or global framework. 48

\section{Means of Implementing the Integrated Management and Sustainable Development of Coastal areas under Chapter 17 of Agenda 21}

In conducting all types of activities for establishing the integrated management and sustainable development of coastal areas, Thailand should provide certain means of implementation which include financing and cost evaluation, scientific and technological means, human resource development and capacity building. In terms of financing and cost evaluation, Thailand must estimate the average cost of implementing the activities, which depends on which strategies and programs that the Thai Government decides. In terms of scientific and technological means, Thailand should cooperate with developed countries for the development of systematic coastal observation, research and information management systems through transfer of environmentally safe technologies and methodologies for sustainable development of coastal and marine areas. 49

As a developing country, Thailand should also seek support from international organizations for the development of technologies and endogenous scientific and technological capacities. For human resource development, Thailand should promote and facilitate the organization of education and training in integrated coastal and marine management and sustainable development. This should be promoted in all groups - scientists, technologists, managers, community-based managers, users, leaders, indigenous peoples, fisher folk, women and youth, among others. Besides management and development, environmental protection concerns and local planning issues should be incorporated in educational curricula and public awareness campaigns and at the same time traditional ecological knowledge and socio-cultural values must not be 
neglected. For capacity-building, Thailand should consider the following issues, if necessary, through bilateral and multilateral development cooperation: (1) ensuring capacity-building at the local level; (2) consulting on coastal and marine issues with local administrations, the business community, the academic sector, resource user groups and the general public; (3) coordinating sectoral programs while building capacity; (4) identifying existing and potential capabilities, facilities and needs for human resources development and scientific and technological infrastructure; (5) developing scientific and technological means and research; (6) promoting and facilitating human resource development and education; (7) supporting "Centers of Excellence" in integrated coastal and marine resource management; and (8) supporting pilot demonstration programs and projects in integrated coastal and marine management. 50

\section{B. Proposals for Introducing ICZM in Thailand}

\section{Conducting National Research Project as the First Step of ICZM Implementation}

To ensure the integrated management and sustainable development of the coastal areas in Thailand, a national research project should be conducted to examine a wide range of coastal activities such as development, tourism, conservation, etc. This research will be used as the first step for implementing ICZM in Thailand by identifying all key components and analyzing major actors, laws, and institutions which influence the management of coastal zone. Based on the output of the research, national strategies to deliver ICZM can be developed. Its scope should cover the whole country while information should be provided to maintain an effective framework of sustainable management of the coastal areas. In addition, the research should also have an in-depth analysis of how various organizations interact in implementing ICZM. In brief, the research's content should cover the following areas: (1) describing characteristics of coastal resources in environmental, economic and social dimensions; (2) identifying various types of actors, laws, institutions and other stockholders having influences on the management and planning of the coastal zones; and (3) analyzing how all relevant institutions can be integrated by identifying gaps, opportunities and overlapping functions. 51

\section{Institutional Arrangement for Implementing ICZM Program}

In general, choice of institutional framework is one of the major factors in initiating any

50 $\quad$ d.

51 Sombat Yumuang, Systematic Geography and Integrated Coastal Zone Management (ICZM) for Thailand, available at http://www.defra.gov.uk/environment/marine/iczm/pdf/wave_8.pdf (last visited on Oct. 10, 2009). 
management program. Institutional framework is particularly important for implementing integrated coastal zone management. Since the concept of ICZM is based on a defined geographic area, the institutional arrangement of that particular area becomes a criterion for the success of ICZM. For example, some organizations must be adjusted in compatibility with ICZM so that they can operate ICZM programs. The arrangement of governmental institutions affects both the development process and the pattern of resource uses, thus, it is regarded as a powerful mechanism in planning, managing and facilitating the coordination among different levels of governmental agencies. 52

The nature and the operation of institutions, including their modes of decisionmaking have significant implications for the implementation of any strategies or plans. Specific institutions for any particular management context can create benefits, reduce conflicts and reflect the needs of the people. They direct and manage the usage of resources that respond to the local conditions. For ICZM, key institutions are required to generate, adapt and disseminate knowledge and technologies that are conducive to local conditions. A well functioning institutional arrangement can also issue effective policies that can represent local interests and reflect benefits. 53

There are several forms of institutional structure that can operate integrated coastal zone management programs. Examples include establishing a new agency, developing an existing agency or setting up an inter-agency commission or council. It is recommended that the government agencies at the provincial level, which consists of representative offices from the central government and local employees in the Provincial Council should be strengthened and should serve as the institutional framework for operating ICZM. The following reasons are used for supporting the role of government agencies at the provincial level in operating ICZM: a) they know the local conditions and understand current situation in their provinces; b) they have their own income via tax collection and can request more through annual plans; c) their current roles of coordination and cooperation in the implementation of integrated works have to be strengthened and made more practical to facilitate the management; d) their administrative system is a combination between de-concentration and decentralization that links local government and central government; e) it helps enhancing public participation and community management also provides chances for local government to make their plans and policies; f) more integrated plans and policies

\footnotetext{
52 Tunnie Srisakulchairak, Enhancement of Integrated Coastal Zone Management in Thailand: Institutional Aspects, submitted to International Symposium on Protection and Management of Coastal Marine Ecosystem, available at http://www.emecs.or.jp/2000thai-sympo/pdf/re-tunnie.pdf (last visited on Oct. 10, 2009).

$53 \quad$ Id.
} 
can be magnified and inconsistency of policies can be minimized; and g) inter-provincial networks can be created and increased to facilitate works in the future. 54

\section{Making ICZM Framework through Enabling Legislation}

As a tool for managing the management system of the coastal areas and also as a means of linking coastal zone issues with environmental issues, the existing laws and regulations are not adequate. Therefore, drafting the specific legislation to enable ICZM for the Thai system is now in process. There are two drafts of the Law on Promotion of Marine and Coastal Resources Management: the first one was proposed by the Department of Marine and Coastal Resources ("DMCR") and the second one was the reviewed version of the first draft made by the Office of the Council of State.

While the second draft focuses on certain aspects with only 39 articles, the first draft has been created in 10 chapters with 134 sections. It may be anticipated that the first draft on promotion of Marine and Coastal Resources Management Act will be revised several times before being submitted to the Secretary-General of the Cabinet and the National Assembly for debate and adoption. The first and second draft of the Law on the Promotion of Marine and Coastal Resources Management in Thailand will be well compared at Annex. Objectives of the first draft are: (1) To implement constitutional guarantee of rights to information and participation in resource management; (2) To provide a framework within which the multiple government authorities operating in the coastal zone and marine areas can coordinate and harmonize their functions; (3) To provide for resolving conflicts of jurisdiction among government authorities and for resolving disputes among stakeholders. Main issues of the first draft are as follows:

1. Participation of local communities in decision-making and benefit sharing.

2. Dissemination for coastal and marine resources management techniques and access to information.

3. Establish the process for recognizing coastal communities and giving them legal personality and provides an inter ministerial, cross-sectoral committee mechanism to coordinate of the governmental actors.

4. Formalize the effective existing practices in preparing management framework (by the coastal communities) and designating competent officers to share the responsibility of implementing and enforcing the law.

5. Establish dispute resolution option in the form of multilateral committee and $\mathrm{Da}$ Toh justice (using in resolving disputes in southern provinces where Islamic law is observed).

6. Facilitate ongoing rehabilitation activities in the coastal provinces affected by the 2004 Tsunami. 
7. Establish the construction set back line along the coast line as the green shield or coastal protected areas (in accordance with the Annotated Guiding Principles for Post - Tsunami Rehabilitation and Reconstruction).

8. Empower local authorities and coastal communities to conserve and manage coastal and marine resources and the environment.

9. Establish the Marine and Coastal Resources Fund at national and provincial levels to provide financial support for the preservation, conservation, restoration and development of resources biodiversity and environment.

10. Prescribes coastal and marine protected area including measures for protection of marine endangered species.

11. Protection of ecological system from impact of pollution by prescribing measures of control and prevention of pollution from coastal sources and release of waste from sea vessels.

12. Prescribing compensation in civil cases against sources for damages to life, body, health and properties including punitive damage.

13. Prescribing compensation for damage from destruction of natural resources, environment and ecological system including civil sanction.

14. Prescribing standards for activities, sports and culture for coastal zone and marine areas in accordance with sufficiency economy.

15. Guidelines for formulating marine and coastal resources policies and plans at national, provincial and local levels for implementation.

16. Regulating independent organisations for coordination of management and auditing.

17. Expand the mandate of Department of Marine and Coastal Resources. Its authority will be strengthened by the fact that it will act on behalf of multisectoral authorities at the national, provincial and local levels.

Since the process of preparing the first draft was done by a research team composed of local lawyers and foreign consultant, the concept of sustainable development was well articulated while the Thai context such as the concept of sufficiency economy was also maintained. Recognizing that conflicts among stakeholders in Thai coastal zones can only be solved by means of integration, both drafts seem to focus on the same term on "integration." However, they elaborate the same word in different ways. While the first draft puts "integration" with "cooperation" and ties them with rights of coastal community and co-management, the second draft puts "integration" with "unity" and see the right of local community only through the participation, not management.

Regarding key terms under definition clauses, the first draft provides numbers of terms 2 time of the second one. Some significant terms defined in the first draft are also missing from the second draft, e.g., sustainable development, coastal community zone, stakeholders, etc. For example, under the first draft, "stakeholders" means government agencies, State agencies, local administration authorities, legal persons including 
commercial and private sector enterprises and entrepreneurs and non-governmental organizations, coastal communities and natural persons that are related to management and activities carried out in the coastal zone and marine areas. By ignoring the importance of "community" as key stakeholder, the second draft provides the management system only at the national level focusing on policy-making and top-down planning.

Unlike the second draft, the first draft provides three levels of management: national, provincial and local, through three levels of authorities namely the National Marine and Coastal Resources Committee, the Provincial Marine and Coastal Resources Committee, and the Local Marine and Coastal Resources Committee, making it both bottom-up and decentralized.

By this means, the second draft cannot fulfill the task on "integration," thus impossible to introduce the ICZM to the Thai coastal zone management. In contrast, the first draft explicitly expresses in Chapter 2 as a Chapter particularly focus on "Community Rights and Integrated Co-Management," providing ICZM together with the concept on co-management between State and community.

\section{Conclusion}

Establishing a viable framework for ICZM in Thailand has many challenges. Currently, the two drafts of laws are in competition. While the first draft provides broader scope in accordance with the interdependence and integration concepts, the second draft focuses more on the unity of coastal zone management in a narrower framework of ICZM. The first draft puts emphasis on institutional integration as well as participation of stakeholders making the coastal management more vertically and horizontally integrated. Under the first draft, all 21 government agencies shall jointly manage the coastal zone in a unified and integrated manner together with the committees at 3 levels. However, the second draft maintains only the national level with narrower scope of authority. At the moment, the final draft of the law is not yet decided. It is interesting to see the development of new law of Thailand on integrated coastal zone management that will be passed by the Parliament. It is also questionable whether the new mechanism like ICZM would be successfully introduced in Thailand.

In terms of community rights, it is even more challenging than the issue on ICZM, since the 1997 Constitution and the 2007 Constitution of Thailand have vested traditional communities including coastal communities with rights and duties to 
manage resources where they live. Part 12 of the 2007 Constitution has a title on "Community Rights" and Section 66 stipulates that:

Persons assembling as to be a community, local community or traditional local community shall have the right to conserve or restore their customs, local wisdom, arts or good culture of their community and of the nation and participate in the management, maintenance and exploitation of natural resources, the environment and biological diversity in a balanced and sustainable fashion.

By using "community rights" through the "co-management" to facilitate the integration of coastal zone management, the ICZM may be more possible in Thailand. 


\section{ANNEX}

\section{Comparison between two Drafts of Law on the Promotion of Marine and Coastal Resources Management in Thailand}

\begin{tabular}{|c|c|c|}
\hline Topic & The First Draft & The Second Draft \\
\hline Objective & $\begin{array}{l}\text { With } 8 \text { goals: } \\
\text { 1) Rehabilitate the degradation of } \\
\text { marine and coastal resources under } \\
\text { the concept of sustainable } \\
\text { development and the sufficiency } \\
\text { economy model; } \\
\text { 2) Make the conservation, rehabilitation } \\
\text { and exploitation of marine and coastal } \\
\text { resources to be managed in the same } \\
\text { direction; } \\
\text { 3) Promote the integration of law } \\
\text { enforcement and operation of relevant } \\
\text { agencies; } \\
\text { 4) Promote the cooperation between } \\
\text { State agencies and people; } \\
\text { 5) Recognize the rights of coastal } \\
\text { community in the co-management of } \\
\text { resources; } \\
\text { 6) Designate the areas for the resources } \\
\text { management; } \\
\text { 7) Establish special Fund for } \\
\text { rehabilitating the resources; and } \\
\text { 8) Establish the system on harmonious } \\
\text { disputes resolution. }\end{array}$ & $\begin{array}{l}\text { With } 4 \text { goals: } \\
\text { 1) Present marine and coastal resources } \\
\text { management doesn' thave unity, } \\
\text { integration and participation of people } \\
\text { and local community; } \\
\text { 2) Drastic degradation of the resources } \\
\text { due to exploitation and invasion; } \\
\text { 3) Existing laws not covering the } \\
\text { protection of resources in some areas; } \\
\text { and } \\
\text { 4) Need managing the management of } \\
\text { the resources, in a balanced and } \\
\text { sustainable way, with participation of } \\
\text { people and local community. }\end{array}$ \\
\hline Definition & $\begin{array}{l}\text { With } 22 \text { key terms: } \\
\text { Sustainable development, island, coastal } \\
\text { community zone, biological diversity, } \\
\text { marine and coastal resources officers, } \\
\text { coast, sea, habitat, marine and coastal } \\
\text { resources, setback, oil, mangrove forests, } \\
\text { beach forests, stakeholders, wetlands, } \\
\text { pollution, ecosystem, Minister, } \\
\text { sufficiency economy, offshore } \\
\text { installations, sources of pollution, and } \\
\text { Director-General (Article 3) }\end{array}$ & $\begin{array}{l}\text { With } 12 \text { key terms: } \\
\text { Marine and coastal resources, pollution, } \\
\text { mangrove forests, marine and coastal } \\
\text { ecology, source of pollution, } \\
\text { conservation zone, the Fund, Committee, } \\
\text { Committee for Managing the Fund, } \\
\text { Officer, Director-General, and Minister. }\end{array}$ \\
\hline
\end{tabular}




\begin{tabular}{|c|c|c|}
\hline Topic & The First Draft & The Second Draft \\
\hline \multirow{12}{*}{$\begin{array}{l}\text { Scope and } \\
\text { Degree of } \\
\text { Unity and } \\
\text { Integration }\end{array}$} & 3.1 Framework: & 3.1 Framework: \\
\hline & Together with others (Committees at 3 & For the marine and coastal resources to \\
\hline & levels: national, provincial, local; & be managed with unity and integration, \\
\hline & $\begin{array}{l}\text { competent officers, coastal community, } \\
\text { and relevant government agencies), }\end{array}$ & $\begin{array}{l}\text { the Cabinet must provide the National } \\
\text { Plan and Policy on the Marine and }\end{array}$ \\
\hline & & $\begin{array}{l}\text { Coastal Resources Management, as } \\
\text { framework and ouideline in }\end{array}$ \\
\hline & $\begin{array}{l}\text { management of marine and coastal } \\
\text { resources, ecosystems and biodiversity, } \\
\text { which shall be jointly managed in a }\end{array}$ & $\begin{array}{l}\text { administering, budgeting, coordinating } \\
\text { and cooperating for the effective } \\
\text { management. (Article 4, para. 1) }\end{array}$ \\
\hline & unified and integrated manner, in & This National Plan will be renewed \\
\hline & $\begin{array}{l}\text { accordance with sufficiency economy } \\
\text { model and sustainable development by }\end{array}$ & $\begin{array}{l}\text { every } 5 \text { years. (Article } 4 \text {, para. 2) Before } \\
\text { the first National Plan is launched the }\end{array}$ \\
\hline & 21 government agencies 57 , who have & Cabinet may adjust the National Plan to \\
\hline & $\begin{array}{l}\text { powers and duties on the management, } \\
\text { under framework of the Act. (Article } 4 \text {, } \\
\text { para. 1) }\end{array}$ & $\begin{array}{l}\text { be appropriate and responding to the } \\
\text { situation that has changed. (Article } 4 \text {, } \\
\text { para. 3) }\end{array}$ \\
\hline & $\begin{array}{l}3.2 \text { Guidelines for the preparation of } \\
\text { laws and policies: }\end{array}$ & $\begin{array}{l}3.2 \text { Guidelines for the preparation of } \\
\text { laws and policies: }\end{array}$ \\
\hline & $\begin{array}{l}\text { Chapter } 3 \text { of this Act provides the } \\
\text { provisions as guidelines for the } \\
\text { preparation of management policies and } \\
\text { plans and the passing of regulations for } \\
\text { the management of marine and coastal } \\
\text { resources and their biodiversity in } \\
\text { accordance with this Act. (Article 70) }\end{array}$ & Being deleted. \\
\hline \multirow{2}{*}{$\begin{array}{l}\text { Various } \\
\text { Authorities }\end{array}$} & 4.1 The Prime Minister: & 4.1 The Prime Minister: \\
\hline & $\begin{array}{l}\text { Power to control, suppress or relieve } \\
\text { adverse effects, in the event of } \\
\text { emergency or danger to public, due to } \\
\text { the spread of pollution, natural disasters } \\
\text { or other causes. (Article 5); Power to }\end{array}$ & $\begin{array}{l}\text { Power of the Prime Minister as the Head } \\
\text { of the Cabinet in providing the National } \\
\text { Plan and Policy on the Marine and } \\
\text { Coastal Resources Management. (Article } \\
\text { 4); Power of the Prime Minister as a }\end{array}$ \\
\hline
\end{tabular}

57 1) Department of Marine and Coastal Resources; 2) National Park; 3) Wildlife and Plant Conservation Department; 4) Royal Forestry Department; 5) Pollution Control Department; 6) Department of Minerals; 7) Promotion of Environmental Quality Department; 8) Office of Natural Resource and Environment Policy and Planning; 9) Fisheries Department (Ministry of Agriculture and Cooperatives); 10) Mineral Fuel Department (Ministry of Energy); 11) Department of Industrial Works (Ministry of Industry); 12) Marine Department (Ministry of Transport); 13) Community Development Department; 14) Local Administration Department; 15) Department of Public Work and Town Planning; 16) Department of Lands (Ministry of Interior); 17) Royal Thai Navy (Ministry of Defense); 18) Royal Thai Police; 19) Office of the Prime Minister; 20) Department of Fine Arts (Ministry of Culture); and 21) Tourism Authority of Thailand. 


\begin{tabular}{|c|c|c|}
\hline Topic & The First Draft & The Second Draft \\
\hline \multirow[t]{4}{*}{$\begin{array}{l}\text { Various } \\
\text { Authorities }\end{array}$} & $\begin{array}{l}\text { designate preventive measures and } \\
\text { make emergency plans in order to } \\
\text { prevent, resolve, suppress or relieve the } \\
\text { emergency and danger in Article } 5 . \\
\text { (Article 6); Power of the Prime Minister } \\
\text { as a Chairman of the National Marine } \\
\text { and Coastal Resources Committee } \\
\text { (Article 8). }\end{array}$ & $\begin{array}{l}\text { Chairman of the National Marine and } \\
\text { Coastal Resources Committee (Article 6). }\end{array}$ \\
\hline & $\begin{array}{l}\text { 4.2 Minister of Natural Resources and } \\
\text { Environment: } \\
\text { Being in charge of the enforcement of } \\
\text { the Act with power to issue Ministerial } \\
\text { Notifications or regulations or rules in } \\
\text { appointing competent officers, setting } \\
\text { fees, and designating other activities for } \\
\text { the execution of the Act. (Article 7); } \\
\text { Power of the Minister of Natural } \\
\text { Resources and Environment as a Vice- } \\
\text { Chairman of the National Marine and } \\
\text { Coastal Resources Committee (Article } \\
\text { 8). }\end{array}$ & $\begin{array}{l}\text { 4.2 Minister of Natural Resources and } \\
\text { Environment: } \\
\text { Being in charge of the enforcement of the } \\
\text { Act, with power to appoint competent } \\
\text { officers, and to issue Ministerial } \\
\text { Notifications or regulations or rules for } \\
\text { the execution of the Act. (Article 5); } \\
\text { Power of the Minister of Natural } \\
\text { Resources and Environment as a Vice- } \\
\text { Chairman of the National Marine and } \\
\text { Coastal Resources Committee (Article 6). }\end{array}$ \\
\hline & $\begin{array}{l}\text { 4.3 Department of Marine and Coastal } \\
\text { Resources (DMCR): } \\
\text { The DMCR is the Secretariat of the } \\
\text { National Marine and Coastal Resources } \\
\text { Committee. (Article 17); Duties of the } \\
\text { DMRC' s Director-General as member } \\
\text { and secretary of the National Marine } \\
\text { and Coastal Resources Committee. } \\
\text { (Article 8), and as member and secretary } \\
\text { of the Marine and Coastal Resources } \\
\text { Fund. (Article 99). }\end{array}$ & $\begin{array}{l}\text { 4.3 Department of Marine and Coastal } \\
\text { Resources (DMCR): } \\
\text { Secretariat Office is to be established } \\
\text { under the DMCR to serve as the } \\
\text { Secretariat of the National Marine and } \\
\text { Coastal Resources Committee. (Article } \\
\text { 15); Duties of the DMRC' s Director- } \\
\text { General as member and secretary of the } \\
\text { National Marine and Coastal Resources } \\
\text { Committee. (Article 6), and as member } \\
\text { and secretary of the Marine and Coastal } \\
\text { Resources Fund. (Article 25). }\end{array}$ \\
\hline & $\begin{array}{l}\text { 4.4 National Marine and Coastal } \\
\text { Resources Committee: } \\
\text { Perform } 19 \text { areas of its functions: } 1 \text { ) } \\
\text { Consider and approve national policies } \\
\text { and plans on marine and coastal } \\
\text { resources management; } 2 \text { ) Give opinions } \\
\text { and suggestions to the Cabinet for } \\
\text { approval of the projects, programs, and }\end{array}$ & $\begin{array}{l}\text { 4.4 National Marine and Coastal } \\
\text { Resources Committee: } \\
\text { Perform } 8 \text { areas of its functions: } 1 \text { ) } \\
\text { Propose national policies and plans on } \\
\text { marine and coastal resources } \\
\text { management to the Cabinet; } 2 \text { ) Monitor } \\
\text { and speed up the operation of the State } \\
\text { agencies and that of the local }\end{array}$ \\
\hline
\end{tabular}




\begin{tabular}{|c|c|c|}
\hline Topic & The First Draft & The Second Draft \\
\hline $\begin{array}{l}\text { Various } \\
\text { Authorities } \\
\text { (cont'd) }\end{array}$ & $\begin{array}{l}\text { investment budgets of State agencies for } \\
\text { the implementation of the national } \\
\text { policies and plans on marine and coastal } \\
\text { resources management; } 3 \text { ) Consider and } \\
\text { approve measures, directions, plans, } \\
\text { projects, budgets, and personnel for the } \\
\text { management of marine and coastal } \\
\text { resources, and their biodiversity, to } \\
\text { serve as a framework for the operation } \\
\text { of State agencies, local administration } \\
\text { authorities, and other relevant agencies, } \\
\text { to implement management policies and } \\
\text { plans, as well as for the use of marine } \\
\text { and coastal resources, and their } \\
\text { biodiversity; } 4 \text { ) Coordinate and arrange } \\
\text { meetings with the other committees set } \\
\text { up pursuant to legislation or Cabinet } \\
\text { resolutions with the functions relating to } \\
\text { marine and coastal resource } \\
\text { management policies and plans; } 5 \text { ) } \\
\text { Coordinate, monitor, assess, and speed } \\
\text { up the operational results of the State } \\
\text { agencies assigned to operate in the field } \\
\text { of marine and coastal resources, and } \\
\text { their biodiversity in accordance with the } \\
\text { national marine and coastal resources } \\
\text { management directions and policies; } 6 \text { ) } \\
\text { Make suggestion for the coordination of } \\
\text { the needs of, and the benefits for, the } \\
\text { stakeholders relevant for the } \\
\text { management, distribution, use, } \\
\text { conservation, restoration, and } \\
\text { development of marine and coastal } \\
\text { resources, and their biodiversity; } 7 \text { ) } \\
\text { Consider and approve provincial } \\
\text { marine and coastal resources } \\
\text { management policies and plans; } 8 \text { ) } \\
\text { Consider and decide appeals lodged in } \\
\text { accordance with this Act; } 9 \text { ) Consider } \\
\text { and approve the issuance of notification } \\
\text { designating marine and coastal } \\
\text { protected areas, as well as the criteria, } \\
\text { conditions, and methods for the } \\
\text { management of those areas; } 10 \text { ) }\end{array}$ & $\begin{array}{l}\text { administration authorities in the field of } \\
\text { marine and coastal resources, in } \\
\text { accordance with the national marine and } \\
\text { coastal resources management policies } \\
\text { and plans; 3) Give opinions and } \\
\text { suggestions to the Cabinet for approval } \\
\text { of the projects, programs, and } \\
\text { investment budgets of State agencies for } \\
\text { the implementation of the national } \\
\text { marine and coastal resources } \\
\text { management policies and plans; } 4 \text { ) Give } \\
\text { opinions to the Cabinet for any direction } \\
\text { when State agencies fail to operate their } \\
\text { functions in accordance with the national } \\
\text { marine and coastal resources } \\
\text { management policies and plans; } 5 \text { ) } \\
\text { Consider and approve the issuance of } \\
\text { notification designating marine and } \\
\text { coastal protected areas; } 6 \text { ) Consider and } \\
\text { approve the issuance of notification } \\
\text { stipulating marine and coastal } \\
\text { environmental quality standards, } \\
\text { standards for controlling the sources of } \\
\text { pollution, and measures for controlling } \\
\text { and solving problems resulting from } \\
\text { pollution; } 7 \text { ) Give suggestions on the } \\
\text { issuance or amendment of Ministerial } \\
\text { Notifications or regulations or rules } \\
\text { according to this Act; } 8 \text { ) Perform any } \\
\text { other functions as required by this Act or } \\
\text { other legislations, or functions as } \\
\text { assigned by the Prime Minister or the } \\
\text { Cabinet. (Article } 14 \text { ) }\end{array}$ \\
\hline
\end{tabular}




\begin{tabular}{|c|c|c|}
\hline Topic & The First Draft & The Second Draft \\
\hline $\begin{array}{l}\text { Various } \\
\text { Authorities } \\
\text { (cont'd) }\end{array}$ & $\begin{array}{l}\text { Consider and approve the issuance of } \\
\text { notification stipulating criteria, } \\
\text { conditions and method for the } \\
\text { preservation, conservation, and } \\
\text { protection of plant and animal species, } \\
\text { and biodiversity; 11) Consider and } \\
\text { approve the issuance of notification } \\
\text { stipulating marine and coastal } \\
\text { environmental quality standards, } \\
\text { pollution control standards, and } \\
\text { pollution control zones; } 12) \text { Stipulate the } \\
\text { criteria, conditions, and methods for the } \\
\text { allocation of the income and grants of } \\
\text { the Provincial Marine and Coastal } \\
\text { Resources Fund; } 13 \text { ) Stipulate the } \\
\text { criteria, conditions, and methods for the } \\
\text { allocation of grants for Provincial } \\
\text { Marine and Coastal Resources Funds } \\
\text { from the Marine and Coastal Resources } \\
\text { Fund; } 14) \text { Stipulate the criteria, } \\
\text { conditions, and methods for operational } \\
\text { standards for tourism, sports, or other } \\
\text { activities in marine and coastal areas; } 15 \text { ) } \\
\text { Stipulate criteria and standards required } \\
\text { to support the preservation of local } \\
\text { culture in the coastal zone and to } \\
\text { promote public awareness of it, in } \\
\text { accordance with the "Sufficiency } \\
\text { Economy" mode and sustainable } \\
\text { development; } 16 \text { ) Monitor the } \\
\text { management of the Marine and Coastal } \\
\text { Resources Fund; } 17) \text { Make suggestions } \\
\text { for complementary measures for the } \\
\text { management and use of marine and } \\
\text { coastal resources, and their biodiversity, } \\
\text { including rewards, tax exemptions, } \\
\text { benefit-sharing, and the right to } \\
\text { sufficient and sustainable use of marine } \\
\text { and coastal resources and ecosystems; } \\
\text { 18) Approve rules, regulations, } \\
\text { notifications, and orders for the } \\
\text { implementation of this Act, as well as to } \\
\text { coordinate the implementation of } \\
\text { policies and plans and the enforcement }\end{array}$ & \\
\hline
\end{tabular}




\begin{tabular}{|c|c|c|}
\hline Topic & The First Draft & The Second Draft \\
\hline \multirow[t]{2}{*}{$\begin{array}{l}\text { Various } \\
\text { Authorities } \\
\text { (cont'd) }\end{array}$} & $\begin{array}{l}\text { of rules, regulations, notifications, and } \\
\text { orders of State agencies, local } \\
\text { administration authorities, and other } \\
\text { agencies relevant for the management of } \\
\text { marine and coastal resources, and their } \\
\text { biodiversity; 19) Perform any other } \\
\text { functions as required by this Act or } \\
\text { other legislation. (Article 16) }\end{array}$ & \\
\hline & $\begin{array}{l}\text { 4.5 Provincial Marine and Coastal } \\
\text { Resources Committee: } \\
\text { Have powers an duties on the following } \\
13 \text { issues: } 1 \text { ) Prepare and propose } \\
\text { Provincial Marine and Coastal } \\
\text { Resources Management Plans to be } \\
\text { submitted for approval by the National } \\
\text { Marine and Coastal Resources } \\
\text { Committee; 2) Consider and approve } \\
\text { Local Marine and Coastal Resources } \\
\text { Management Plans; } 3 \text { ) Consider and } \\
\text { approve the establishment, adjustment, } \\
\text { and withdrawal of a coastal community } \\
\text { and a coastal community; } 4 \text { ) Consider } \\
\text { and approve permits for use of areas in } \\
\text { a coastal community zone for other } \\
\text { public benefits; } 5 \text { ) Stipulate the criteria, } \\
\text { conditions, and methods for allocating } \\
\text { the income of the Provincial Marine and } \\
\text { Coastal Resources Fund from local } \\
\text { administration authorities in the coastal } \\
\text { community zone, as well as to supervise } \\
\text { the management of the Provincial } \\
\text { Marine and Coastal Resources Fund; } 6 \text { ) } \\
\text { Consider and approve the permits for } \\
\text { access to conduct research in a coastal } \\
\text { community zone, as well as to protect } \\
\text { traditional knowledge; } 7 \text { ) Consider and } \\
\text { decide appeals lodged pursuant to this } \\
\text { Act; } 8 \text { ) Consider and approve the } \\
\text { issuance of notifications, orders, and } \\
\text { rules; 9) Give comments and make } \\
\text { suggestions for the Cabinet in } \\
\text { considering approval of projects and } \\
\text { work plans, as well as investment }\end{array}$ & \\
\hline
\end{tabular}




\begin{tabular}{|c|c|c|}
\hline Topic & The First Draft & The Second Draft \\
\hline \multirow[t]{2}{*}{$\begin{array}{l}\text { Various } \\
\text { Authorities } \\
\text { (cont'd) }\end{array}$} & $\begin{array}{l}\text { budgets of State agencies in order to } \\
\text { operate in accordance with National } \\
\text { Marines and Coastal Resources } \\
\text { Management Policies and Plans; 10) } \\
\text { Stipulate the criteria, conditions and } \\
\text { methods related to operational } \\
\text { standards for tourism, sports, and other } \\
\text { activities in the marine and coastal areas } \\
\text { of the province; 11) Stipulate criteria } \\
\text { and standards required to support the } \\
\text { preservation of local culture in the } \\
\text { coastal zone and promote public } \\
\text { awareness of it, in accordance with the } \\
\text { "Sufficiency Economy" model and } \\
\text { sustainable development; 12) Arrange } \\
\text { for the system of preliminary dispute } \\
\text { settlement by means of a multilateral } \\
\text { committee, mediation, "Da Toh" Justice, } \\
\text { or arbitration, for disputes, conflicts, or } \\
\text { lawsuits relating to marine and coastal } \\
\text { resources and their biodiversity; and 13) } \\
\text { Perform any other functions as required } \\
\text { by this Act or other legislation. (Article } \\
22 \text { ) }\end{array}$ & \\
\hline & $\begin{array}{l}\text { 4.6 Local Marine and Coastal } \\
\text { Resources Committee: } \\
\text { Have powers an duties on the following } \\
11 \text { issues: } 1 \text { ) Make local marine and } \\
\text { coastal resources management plans to } \\
\text { be approved by the Provincial Marine } \\
\text { and Coastal Resources Committee; 2) } \\
\text { Cooperate with Marine and Coastal } \\
\text { Resources Offices on the provision of } \\
\text { boundary posts, signs or other marks } \\
\text { regarding the coastal community and } \\
\text { coastal community zone; } 3 \text { ) Issue } \\
\text { regulations regarding the coastal } \\
\text { community and community zone } \\
\text { management, and the management of } \\
\text { the coastal community's central } \\
\text { properties, in accordance with the } \\
\text { objectives of the coastal community and } \\
\text { compatible with the Committee's }\end{array}$ & $\begin{array}{l}\text { 4.6 Local Marine and Coastal } \\
\text { Resources Committee: } \\
\text { Being deleted. }\end{array}$ \\
\hline
\end{tabular}




\begin{tabular}{|c|c|c|}
\hline Topic & The First Draft & The Second Draft \\
\hline \multirow[t]{2}{*}{$\begin{array}{l}\text { Various } \\
\text { Authorities } \\
\text { (cont'd) }\end{array}$} & $\begin{array}{l}\text { regulations; 4) Supervise and maintain } \\
\text { the coastal community' s central } \\
\text { properties; 5) Supervise compliance } \\
\text { with this Act by residents of the coastal } \\
\text { community; 6) Order any person to } \\
\text { leave the coastal community zone or } \\
\text { take action or refrain from any action in } \\
\text { the coastal community zone in order to } \\
\text { comply with the regulations under } \\
\text { clause (3) or this Act; 7) Conciliate, } \\
\text { mediate, arbitrate or use any other } \\
\text { means of dispute resolution in } \\
\text { accordance with law, when conflicts and } \\
\text { dispute arise among the coastal } \\
\text { community residents regarding marine } \\
\text { and coastal resources management; } 8 \text { ) } \\
\text { Assist the Marine and Coastal Resources } \\
\text { Officers in performing their duty to } \\
\text { prevent violations and prosecute } \\
\text { offenders under this Act; 9) Arrange for } \\
\text { joint consultations; 10) Take any action } \\
\text { deemed appropriate to prevent or } \\
\text { alleviate damage to the coastal } \\
\text { community ; 11) Carry out any other } \\
\text { activities as specified in this Act or as } \\
\text { specified by the National Marine and } \\
\text { Coastal Resources Committee or the } \\
\text { Provincial Marine and Coastal } \\
\text { Resources Committee as the duties of } \\
\text { the Local Marine and Coastal Resources } \\
\text { Committee. (Article 26) }\end{array}$ & \\
\hline & $\begin{array}{l}\text { 4.7 Competent Officers: } \\
\text { With no specific definition given in } \\
\text { Article } 3 \text { of this Act, Officers under this } \\
\text { Act is specifically defined under Chapter } \\
7 \text { as the Marine and Coastal Resources } \\
\text { Officers composed of } 3 \text { categories: } 1 \text { ) } \\
\text { Persons appointed by the Minister from } \\
\text { among government officers under this } \\
\text { Act; and } 2 \text { ) Persons appointed as } \\
\text { competent officers under the main } 11 \\
\text { laws58 and other relevant laws; and } 3 \text { ) }\end{array}$ & $\begin{array}{l}\text { 4.7 Competent Officers: } \\
\text { Officers are defined as persons who are } \\
\text { appointed by the Minister for } \\
\text { undertaking their missions according to } \\
\text { this Act, while Minister is defined as the } \\
\text { Minister of Natural Resources and } \\
\text { Environment. (Article 3) }\end{array}$ \\
\hline
\end{tabular}

58 1) Forest Act B.E. 2484; 2) Fisheries Act B.E. 2490; 3) National Parks Act B.E. 2504; 4) Private Irrigation Act B.E. 


\begin{tabular}{|c|c|c|}
\hline Topic & The First Draft & The Second Draft \\
\hline $\begin{array}{l}\text { Various } \\
\text { Authorities } \\
\text { (cont'd) }\end{array}$ & $\begin{array}{l}\text { Marine and Coastal Resources Officers, } \\
\text { who shall have functions under this Act, } \\
\text { and other relevant laws, as well as, } \\
\text { functions in accordance with the order } \\
\text { of the Minister in charge of the } \\
\text { implementation of such laws. (Article } \\
\text { 112) }\end{array}$ & \\
\hline $\begin{array}{l}\text { Componen } \\
\text { ts and } \\
\text { Order of } \\
\text { Content }\end{array}$ & $\begin{array}{l}\text { Have } 10 \text { Chapters with } 134 \text { Articles: } \\
\text { Chapter 1- General Management: } \\
\text { Part I - National Marine and Coastal } \\
\text { Resources Committee, } \\
\text { Part II - Provincial Marine and Coastal } \\
\text { Resources Committee; } \\
\text { Chapter 2- Community Rights and } \\
\text { Integrated Co-management: } \\
\text { Part I - Local Marine and Coastal } \\
\text { Resources Committee, } \\
\text { Part II - Community Rights and } \\
\text { Establishment and Management of } \\
\text { Coastal Communities, } \\
\text { Part III - Co-Management by People, } \\
\text { Coastal Communities and Local } \\
\text { Administration Authorities, } \\
\text { Part IV - Co-Management by } \\
\text { Stakeholders and Technical Operation } \\
\text { and Collaboration Task Forces; } \\
\text { Chapter } 3 \text { - Marine and Coastal } \\
\underline{\text { Resources Management Policies and }} \\
\text { Plans; } \\
\text { Chapter } 4 \text { - Marine and Coastal } \\
\text { Resources: } \\
\text { Part I - Designation of Management } \\
\text { Areas, } \\
\text { Part II - Management of Marine and } \\
\text { Coastal Resources and Ecosystems, }\end{array}$ & $\begin{array}{l}\text { Have } 7 \text { Chapters with } 39 \text { Articles: } \\
\text { Chapter 1- National Marine and Coastal } \\
\text { Resources Committee; } \\
\text { Chapter 2- Coastal Community; } \\
\underline{\text { Resources Fund; }} \\
\text { Chapter } 4 \text { - Marine and Coastal } \\
\underline{\text { Coastal Resources; }}\end{array}$ \\
\hline
\end{tabular}

2482; 5) Public Irrigation Act B.E. 2485; 6) Land Code, 7) Minerals Act B.E. 2510; 8) Building Control Act B.E. 2522; 9) Thai Territorial Waters Navigation Act B.E. 2456; 10) Tourism Authority of Thailand Act B.E. 2522; and 11) Enhancement and Conservation of National Environmental Quality Act B.E. 2535. 


\begin{tabular}{|c|c|c|}
\hline Topic & The First Draft & The Second Draft \\
\hline & $\begin{array}{l}\text { Part III - Management of Marine and } \\
\text { Coastal Pollution; } \\
\text { Chapter } 5 \text { - Marine and Coastal } \\
\text { Activities and Cultures: } \\
\text { Part I - Management of Marine and } \\
\text { Coastal Resources for Marine and } \\
\text { Coastal Tourism, Sport and Activities, } \\
\text { Part II - Management of Marine and } \\
\text { Coastal Cultures; } \\
\text { Chapter } 6 \text { - Financial Support Measures: } \\
\text { Part I - Marine and Coastal Resources } \\
\text { Fund, } \\
\text { Part II - Provincial Marine and Coastal } \\
\text { Resources Fund; } \\
\text { Chapter } 7 \text { - Marine and Coastal } \\
\underline{\text { Resources Officers; }} \\
\underline{\text { Chapter } 8 \text { - Civil Liability; }} \\
\underline{\text { Chapter } 9 \text { - Dispute Management and }} \\
\underline{\text { Resolution ; and }} \\
\underline{\text { Chapter } 10 \text { - Penalties. }}\end{array}$ & $\begin{array}{l}\frac{\text { Chapter } 5 \text { - Management on }}{\text { Harmonious Dispute Resolution; }} \\
\text { Chapter } 6 \text { - Competent Officers; and } \\
\text { Chapter } 7 \text { - Penalties. }\end{array}$ \\
\hline
\end{tabular}

